\title{
SCREENING FOR A 10-GENE PANEL IN A GROUP OF 90 PHAEOCHROMOCYTOMAS
}

\author{
Emilia Sbardella ${ }^{1,4}$, Radu Mihai ${ }^{2}$, Treena Cranston ${ }^{3}$, Ashley Grossman ${ }^{1}$ \\ Departments of ${ }^{1}$ Endocrinology, Oxford Centre for Diabetes, Endocrinology and Metabolism, ${ }^{2}$ Endocrine Surgery and ${ }^{3} \mathrm{Clinical}$ Genetics
} Oxford University Hospitals NHS Foundations Trust, Oxford, UK

${ }_{4}^{4}$ Department of Experimental Medicine, Sapienza University of Rome, Italy

\section{Background}

Several new gene mutations have been reported in recent years to be associated with a risk of familial phaeochromocytomas. However, it remains unclear as to whether there is a genotype-phenotype correlation that could be used in clinical decisions in a similar fashion as is currently done for RET and VHL mutations

\section{Methods}

Clinical data of consecutive unselected as operated for phaeochromocytomas (PHAEOs) over a decade in a tertiary referral centre were reviewed. Genetic screening was performed using a 10gene panel comprising RET, VHL, SDHB, SDHD, SDHA, SDHC, SDHAF2, MAX, TMEM127 (TMEM127 and SDHB if $>45$ years, NF1 when indicated)

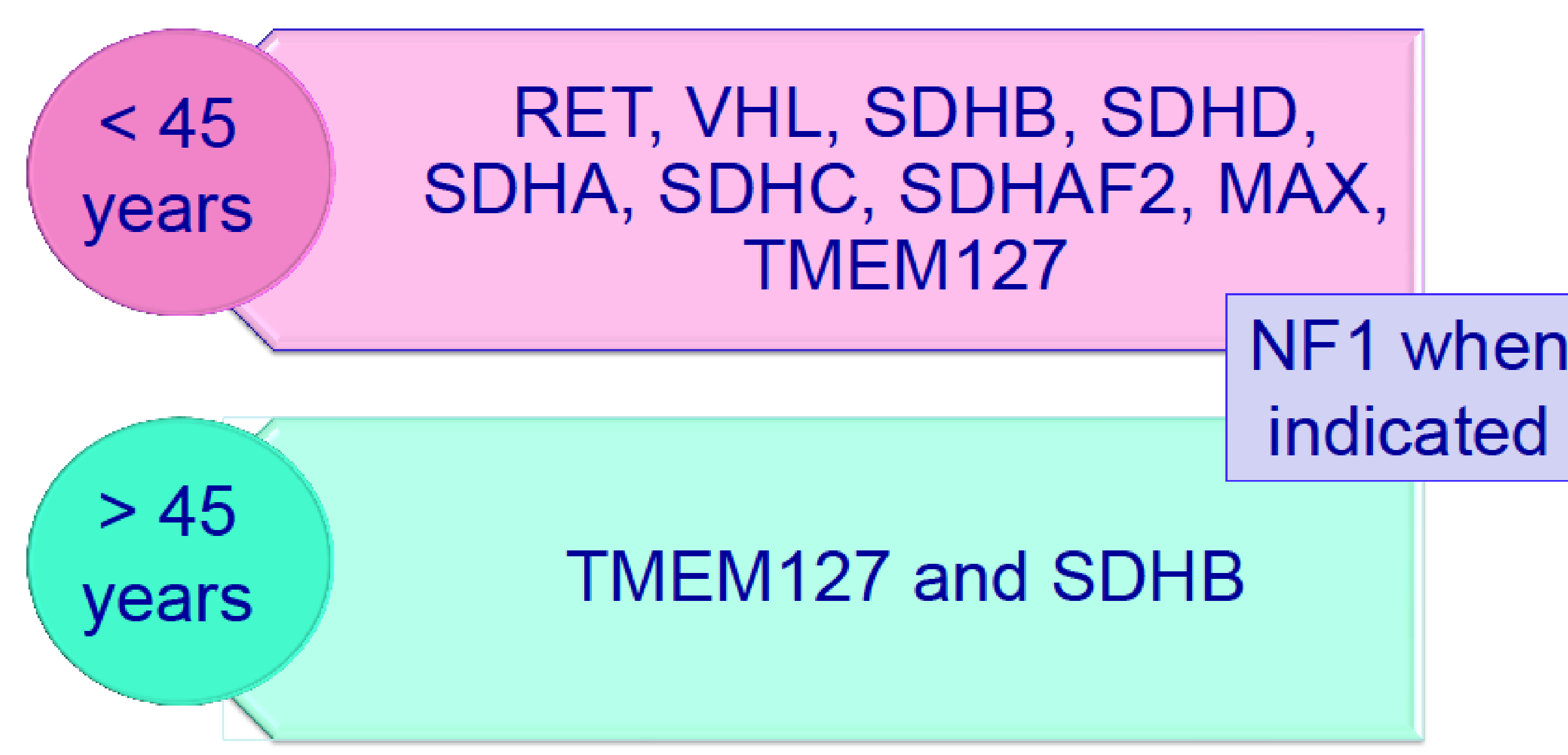

Fig. 1: Genetic screening according to age at presentation

\section{Results}

A total of 157 patients ( 68 males: $43 \%, 89$ females: $57 \%$ 6-86 years, median $50.3 \pm 17.4$ years) underwent laparoscopic $(85 \%)$, open (10.5\%), or laparoscopic converted to open (4.5\%) adrenalectomy for unilateral (92\%) or bilateral (8\%) adrenal phaeochromocytomas: 90 patients underwent genetic screening, in particular 60/90 (67\%) patients presented with apparently sporadic tumours and $30 / 90(33 \%)$ patients had genetic mutations. These were more frequently bilateral $(p=0.02)$. In particular, mutations were seen in 11/90 patients for VHL (12\%), 9/90 NF1 (10\%), 6/90 RET (7\%), $2 / 90$ patients SDHD $(2 \%)$ and 2 patients MAX (2\%). During a median follow-up of 50.4 months (1-240 months), 12 patients $(8 \%)$ presented with recurrence in the controlateral adrenal $(n=8: 5 \%)$ or with metastatic disease from malignant phaeochromocytomas $(n=11: 7 \%)$. Younger patients showed a significant higher percentage of mutations compared to older patients (24/54: $44 \%$ vs 6/36: $17 \%)$; 20/74 (27\%) mutations were identified in patients who presented with unilateral phaeochromocytoma and showed no disease recurrence within 5 years vs $10 / 16$ (62\%) in the recurrentbilateral-metastatic group. 6/7 (86\%) patients with bilateral disease had germline mutations (2 VHL, 2 RET, $1 \mathrm{NF1}, 1 \mathrm{MAX})$

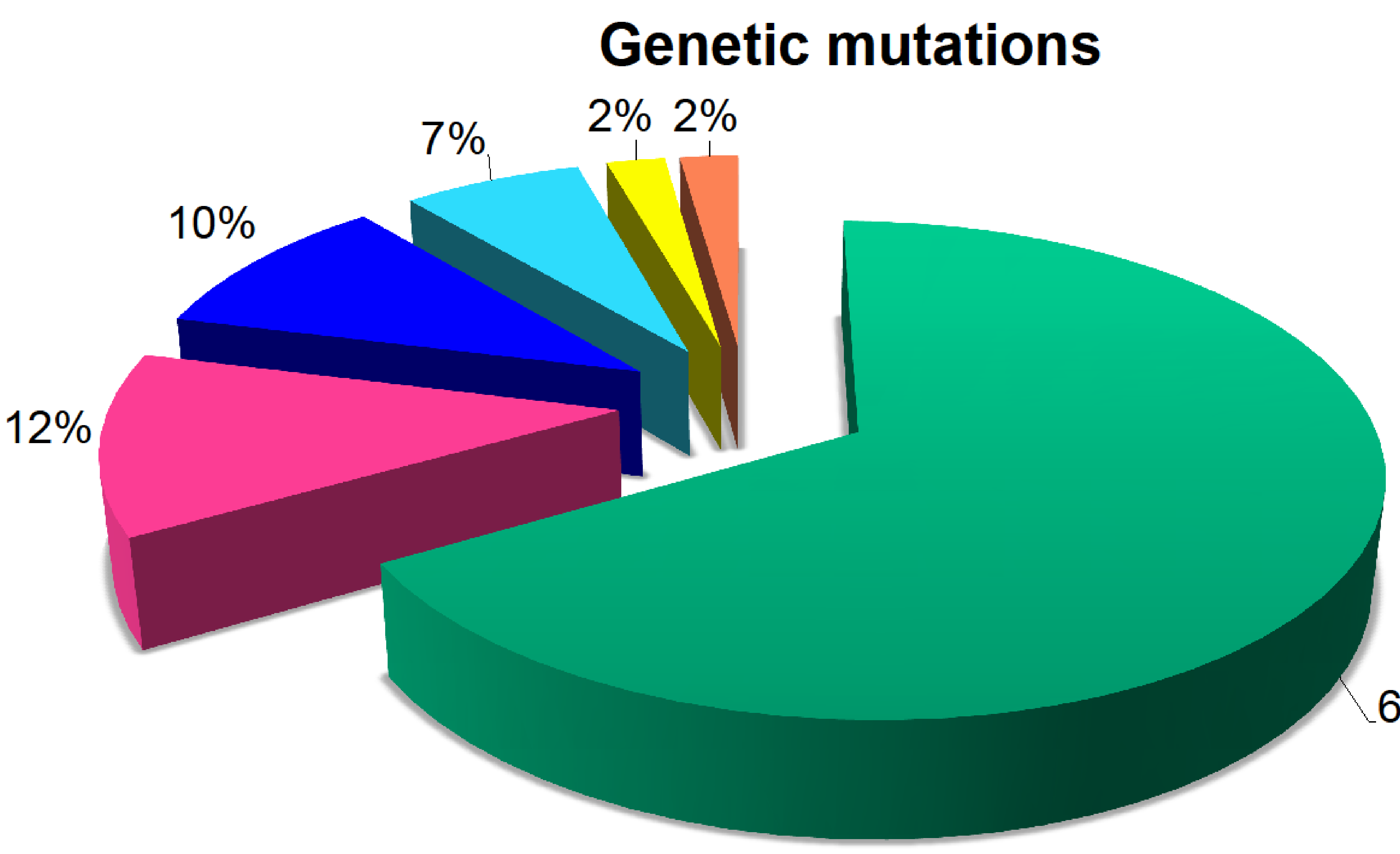

Fig. 2: Distribution of genetic mutations in our population

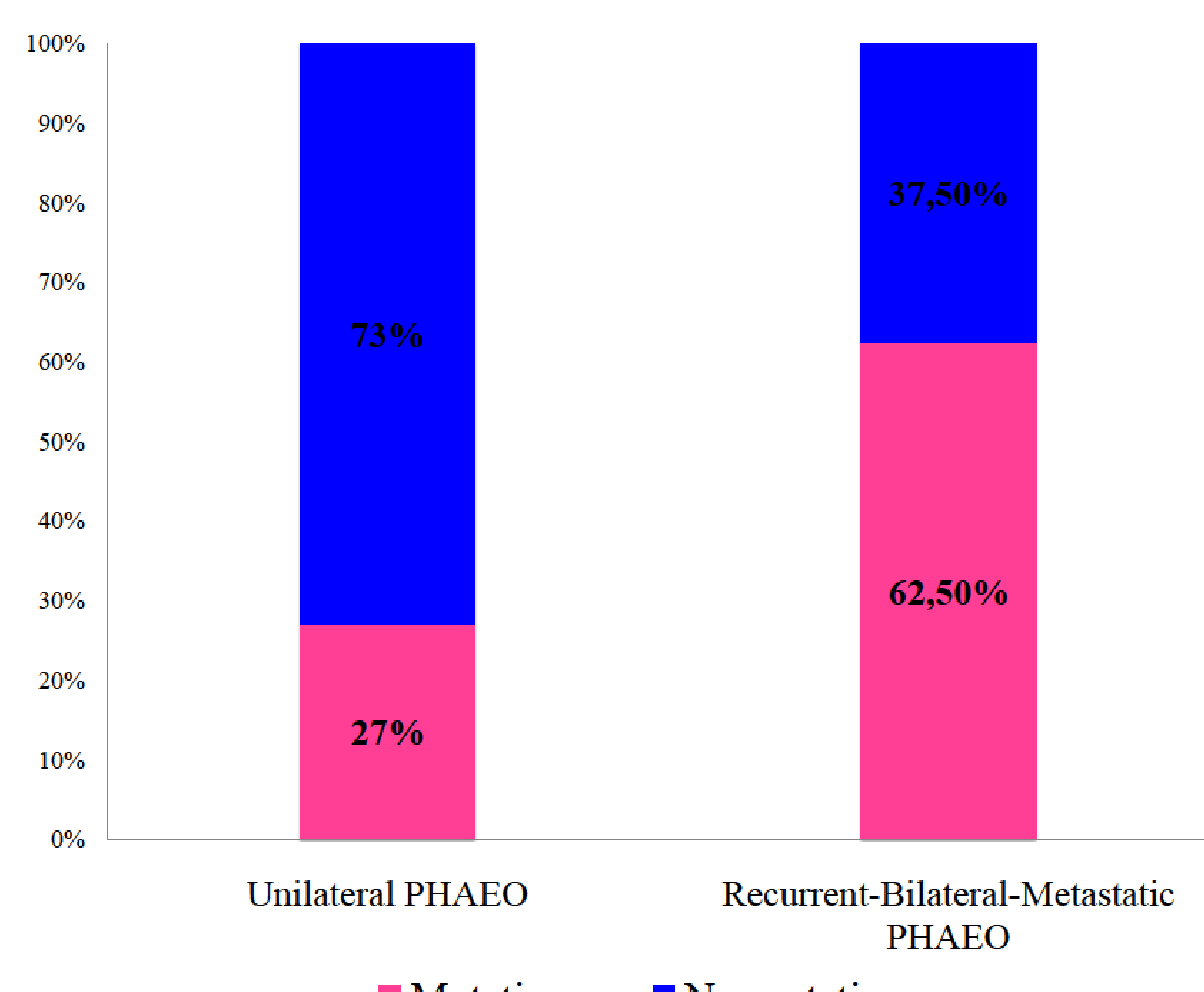

Mutations No-mutations

Fig. 3: Distribution of genetic mutations in unilateral vs recurrent-bilateralmetastatic PHAEO

\section{Conclusions}

The advent of rapid genetic screening for 10-gene panel makes it feasible to screen large cohorts of patients, and allows for the prediction of bilateral and malignant disease and screening of family members.

\section{References}

-Plouin PF, Amar L, Dekkers OM, Fassnacht M, Gimenez-Roqueplo AP, Lenders JW, Lussey-Lepoutre C, Steichen O; Guideline Working Group European Society of Endocrinology Clinical Practice Guideline for long-term followup of patients operated on for a phaeochromocytoma or a paraganglioma. Eur J Endocrinol. 2016 May;174(5):G1-G10 -Jafri M, Maher ER. The genetics of phaeochromocytoma: using clinical features to guide genetic testing. Eur $J$ Endocrinol 2012 Feb; 166(2):151-8

-Chrisoulidou A, Kaltsas G, llias I \& Grossman AB. The diagnosis and management of malignant phaeochromocytoma and paraganglioma. Endocrine-Related Cancer 200714 569-586.

, Schiavi F, Cascon A, Q , Gobledo M, Dahia PL Spectrum and prevalence of FP/TMEM127 gene mutations in pheochromocytomas and paragangliomas. JAMA. 2010 Dec 15;304(23):2611-9.

Eisenhofer G \& Peitzsch M. Laboratory evaluation of pheochromocytoma and paraganglioma Clinical Chemistry 2014 $60 ; 1486-1499$.
-Currás-Freixes M. et al Recommendations for somatic and germline genetic testing of single

pheochromocytoma pheochromocytoma and paraganglioma based on findings from a series of 329 patients. J Med Genet. 2015 Oct;52(10):647-56

Lenders JW, Duh QY, Eisenhofer G, Gimenez-Roqueplo AP, Grebe SK, Murad MH, Naruse M, Pacak K \& Young WF Jr \& Endocrine Society. Pheochromocytoma and paraganglioma: an Endocrine Society Clinical Practice Guideline. Journal of Clinical Endocrinology and Metabolism 201499 1915-1942.

-DeLellis RA, Lloyd RV, Heitz PU \& Eng C. 2004 World Health Organization classification of tumours. In Pathology and Gentics of Tumour of Endocrine Organs. Lyon. IARC Press, 147-158

. from genetics to personalized $511101-111$.

-Amar L, Baudin E, Burnichon N, Peyrard S, Silvera S, Bertherat J, Bertagna X, Schlumberger M, Jeunemaitre X, Succinate dehydrogenase $B$ gene mutations predict survival in patients with malignant pheochromocytomas or paragangliomas. Journal of Clinical Endocrinology and Metabolism 200792 3822-3828. 